\title{
Effect of Zinc Supplementation on Haematological Parameters, Biochemical Components of Blood and Rumen Fluid, and Accumulation of Zinc in Different Organs of Goats
}

\author{
EImas Ulutaş ${ }^{1 * *}$, Abdullah Eryavuz ${ }^{2}$, Aziz Bülbül², Abdur Rahman ${ }^{3, *}$, \\ İsmail Küçükkurt ${ }^{4}$ and Cangir Uyarlar ${ }^{5}$ \\ ${ }^{1}$ Department of Physiology, Faculty of Veterinary Medicine, Yozgat Bozok \\ University, Yozgat, Turkey \\ ${ }^{2}$ Department of Physiology, Faculty of Veterinary Medicine, Afyon Kocatepe \\ University, Afyonkarahisar, Turkey \\ ${ }^{3}$ Department of Animal Nutrition, University of Veterinary and Animal Sciences, \\ (Jhang Campus), Jhang, Pakistan \\ ${ }^{4}$ Department of Biochemistry, Faculty of Veterinary Medicine, Afyon Kocatepe \\ University, Afyonkarahisar, Turkey \\ ${ }^{5}$ Department of Animal Nutrition and Nutritional Diseases, Faculty of Veterinary \\ Medicine, Afyon Kocatepe University, Afyonkarahisar, Turkey
}

\begin{tabular}{l} 
Article Information \\
Received 03 June 2019 \\
Revised 29 July 2019 \\
Accepted 02 September 2019 \\
Available online 28 February 2020 \\
Authors' Contribution \\
EU presented the concept of the study \\
while AE supervised it. AB, EU, IK \\
and CU contributed in trials and \\
lab analysis. EU and AR wrote the \\
manuscript. \\
Key words \\
\hline Zinc, Oxidative status, Essential \\
minerals, Rumen protozoa, Angora \\
goat.
\end{tabular}

\section{A B S T R A C T}

This study was aimed to determine the effects of diet containing high zinc on rumen fermentation, blood parameters, live weight and oxidative status in goats. In this study, twenty four male Angora goats each of 12 months of age, and weighing approximately $35 \mathrm{~kg}$ were divided into four groups as: control group (C) fed with basal diet containing $31.76 \mathrm{ppm} \mathrm{Zn}$, experimental group 1 fed with basal diet supplemented with $500 \mathrm{ppm} \mathrm{Zn}$, experimental group 2 fed with basal diet supplemented with $750 \mathrm{ppm} \mathrm{Zn}$ and experimental group 3 fed with basal diet supplemented with $1000 \mathrm{ppm}$ zinc sulphate. The investigation was started after 15 days of adaptation period and lasted for 30 days. On days 15 and 30 of the study body weight of the animals was recorded, blood and rumen samples were collected. There were no differences in body weight with different levels of Zn supplementation. Red blood cells (RBC) and haemoglobin levels increased $(\mathrm{p}<0.05)$ as compared to control group on the $30^{\text {th }}$ day with $\mathrm{Zn}$ supplementation. High $\mathrm{Zn}$ supplementation increased $(\mathrm{p}<0.05)$ plasma urea nitrogen and glutathione but decreased $(\mathrm{p}<0.05)$ leptin and malondialdehyde concentration while other parameters remained unaffected. No difference was observed in ruminal $\mathrm{pH}$ between the treatment groups. Ruminal ammonia and number of protozoa were decreased $(\mathrm{p}<0.05)$ with $700 \mathrm{ppm}$ and $1000 \mathrm{ppm}$ zinc supplementation. Rumen $\mathrm{Zn}$ concentration increased $(p<0.05)$ in the goats fed with $1000 \mathrm{ppm}$ zinc, whereas there was no difference in rumen $\mathrm{Fe}$ and $\mathrm{Cu}$ concentration among the treatments, except for $1000 \mathrm{ppm}$ zinc supplementation. High zinc supplementation to diet increased $(\mathrm{p}<0.05)$ the liver $\mathrm{Zn}$ and Fe concentrations and mohair Fe levels but decreased the kidney $\mathrm{Cu}$ concentrations. It was concluded that the goats can tolerate the supplementation of high zinc in diet.

\section{INTRODUCTION}

$\mathrm{G}$ at farming, a short term profitable business with a significant contribution of animal origin products in human food and has a direct impact on the socio-economic values of human population especially in under developed areas (Dubeuf et al., 2004). Goat farming is environmentally friendly and works as preservative of natural habitat and

\footnotetext{
Corresponding authors: abdurrehman@uvas.edu.pk; elmas.ulutas@bozok.edu.tr 0030-9923/2020/0003-0977 \$ 9.00/0

Copyright 2020 Zoological Society of Pakistan
}

eliminate the weeds and control their growth. It has a prime importance in terms of income in less privileged areas and majority of population is raising goats for their livelihood. Goat rearing is practised mainly as a protein source like mutton, milk and allied products. With these attributes, goat population has increased by $33.8 \%$ with major contribution of Asia of 59.4\% (Skapetas and Bampidis, 2016) in total worlds goat population of 1.002 billion (FAO, 2018) while share of Asia and Africa in total meat production is $69.8 \%$ and $23.8 \%$, respectively (FAO, 2019). The purpose of goat rearing varies geographically either for meat, milk or mohair production. 
Goat is an efficient grazer of herbs and shrubs and need less capital for maintenance and growth. Profitable goat farming is only possible when goat is fed a balanced diet according to his production needs. A specific feeding strategy should be adopted to fulfil the nutrient requirements of goat especially when being reared for specific purpose like for mohair production. Among the other nutrients, minerals have an influencing role in mohair production (Froetscher et al 2005). These play various roles in the animal body including metabolic reactions, regulation of osmotic pressure, transport system, enzyme synthesis, hormonal balance (Suttle, 2010; Kundu et al., 2014) and has influence on rumen fermentation process in small ruminants (Mallaki et al., 2015). Requirement of these minerals vary depending upon the production factors (hair, dairy or mutton) (Suttle, 2010) and these requirements are not well documented in goat feeding especially for micro minerals.

Zinc is a micro mineral and one of the essential elements required for better growth, production, and reproduction of animals by influencing carbohydrate, energy, protein and nucleic acid metabolism that affects both the immune system and general health status (NRC, 1980; Droke et al., 1998; Suttle, 2010; Pavlata et al., 2011). It is involved in a large number of enzyme systems as a catalytic, co-catalytic or structural component (Reilly, 2004). In the literature, there is a small number of studies on the trace mineral metabolism of the goats among ruminant animal species, compared to cattle and sheep, and these studies are mostly aimed to determine the effects of trace mineral deficiencies on goats or identifying minimum trace mineral requirements. Research data on the effects of zinc supplementation on the performance, nutrient utilization and plasma zinc levels of goats are limited (Jia et al., 2008). This study aims to investigate the effects of high levels of zinc supplementation on the haematological and some biochemical parameters as well as on the rumen fermentation in goats ration to improve the health status and performance of goats.

\section{MATERIALS AND METHODS}

\section{Animals, diets, and experimental design}

Ethics Committee approval was obtained from Afyon Kocatepe University Animal Ethics Committee (B.30.2. AKÜ. 0.0.A2.00.000/272) for this study. A total of 24 almost one-year-old healthy male Angora goats with an average live weight of $34.85 \pm 3 \mathrm{~kg}$ were used. The animals were fed total mix ration two times a day (08:00A.M., 08:00 P.M.) to meet their daily nutrient requirements as described by the National Research Council (2007) and were given free access to water (Tables I, II). Following the 15-day adaptation period (Farenzena et al., 2017), blood samples were collected from animals to determine the zinc levels. Goats were divided into four groups each of six experimental animals in a way that the zinc levels were close to each other. The animals were weighed at the beginning of the study, at the $15^{\text {th }}$ and $30^{\text {th }}$ day by using cattle weighing scale (Dikomsan, RCV-600) to determine their body weights. Animals in the control group were fed with basal ration, whereas animals in the experiment group 1,2 and 3 were fed with basal ration supplemented with 500 ppm, 750 ppm, and 1000 ppm zinc, respectively. Zinc sulphate (zinc sulphate heptahydrate pure, $\mathrm{ZnSO}_{4} \cdot 7 \mathrm{H}_{2} \mathrm{O}$, $1 \mathrm{~kg}$, Kartal Kimya, Ankara, Turkey) as a zinc source was added in concentrate ration. Zinc analyses of the ration samples taken from the groups were performed on the Inductively Coupled Plasma Mass Spectrometer (ICP-MS) (Agilent Technologies, ASX-500, Model No. 63286A) using the method specified in the operating instructions of the instrument (Zhou et al., 2017).

Table I.- Composition of ration used in the study (\% dry matter).

\begin{tabular}{lc}
\hline Parameters & Percentage \\
\hline Ration & \\
Dry matter (kg/day) & 1.2 \\
Ingredients used in ration & \\
Barley straw & 52.74 \\
Alfalfa & 32.14 \\
Concentrated feed mix & 15.12 \\
Chemical composition of ration & \\
Metabolic energy (Mcal/kg) & 2.16 \\
Crude protein & 10.1 \\
Metabolic protein & 7.1 \\
Rumen degradable protein & 3.9 \\
Bypass protein & 2.1 \\
\hline
\end{tabular}

\section{Sample collection}

On the $15^{\text {th }}$ and $30^{\text {th }}$ days of the study, the rumen region of the animals was given massage before the morning feeding for mixing of the rumen contents. The local made rumen catheter with an inner diameter of 5-6 $\mathrm{mm}$ was inserted into rumen via oesophagus and rumen fluid samples were collected from the ventral ruminal sac with the help of a large volume injector and first $10 \mathrm{ml}$ was discarded to avoid saliva contamination. Blood samples were taken using gel and heparin tube from the internal jugular vein. Plasma and serum samples obtained by the centrifugation $\left(1500 \mathrm{~g}, 4^{\circ} \mathrm{C}, 15 \mathrm{~min}\right)$ of blood samples (Nüve, NF 1000R) were stored in the freezer at $-20^{\circ} \mathrm{C}$ until the time of analysis. The mohair samples taken from the animals at the end of the experiment were obtained from 
the region sheared before the trial. At the end of the trial, the animals were slaughtered in a private slaughterhouse and their liver, pancreas, and kidney tissue samples were collected, frozen at $-80^{\circ} \mathrm{C}$ and then analysed through ICPMS (Yuan et al., 2014).

Table II.- Composition of feed ingredients and nutrients in concentrate mix $(\%)$.

\begin{tabular}{lcccc}
\hline & Control & $\begin{array}{c}\mathbf{5 0 0} \\
\text { ppm }\end{array}$ & $\begin{array}{c}\mathbf{7 5 0} \\
\mathbf{p p m}\end{array}$ & $\begin{array}{c}\mathbf{1 0 0 0} \\
\mathbf{p p m}\end{array}$ \\
\hline Feed ingredient & & & & \\
Barley & 50.7 & 50.7 & 50.7 & 50.7 \\
Maize & 30 & 30 & 30 & 30 \\
Sunflower seed meal & 10 & 9.47 & 9.27 & 9.07 \\
Soybean expeller & 7.3 & 7.61 & 7.7 & 7.79 \\
Lime & 1.5 & 1.5 & 1.5 & 1.5 \\
Salt & 0.5 & 0.5 & 0.5 & 0.5 \\
Zinc sulphate & 0 & 0.22 & 0.33 & 0.44 \\
Nutrient composition & & & & \\
Metaboliseable & 2.68 & 2.68 & 2.68 & 2.68 \\
energy (Mcal/kg) & & & & \\
Crude protein & 15.2 & 15.2 & 15.2 & 15.2 \\
Crude cellulose & 5.3 & 5.3 & 5.3 & 5.3 \\
ADF & 6.8 & 6.9 & 6.9 & 6.9 \\
NDF & 16.7 & 16.6 & 16.6 & 16.7 \\
Ca & 0.6 & 0.6 & 0.6 & 0.6 \\
P & 0.4 & 0.4 & 0.4 & 0.4 \\
Na & 0.2 & 0.2 & 0.2 & 0.2 \\
\hline
\end{tabular}

ADF, Acid detergent fiber; NDF, Neutral detergent fiber; $\mathrm{Ca}$, Calcium; $\mathrm{P}$, Phosphorous; Na, Sodium.

\section{Analysis of rumen samples}

Rumen fluid samples were collected and their $\mathrm{pH}$ values were measured with digital $\mathrm{pH}$-meter (Hanna Instruments $\mathrm{pH}$ meter). Rumen contents were determined by ELISA (Thermo Scientific, Multiskan FC, Finland, Cat No: 51119000/51119050/51119100/51119150) using ammonia assay kit (Sigma, AA0100, USA). Protozoan count of the rumen was based on the values reported by Sulu et al. (1988). Zinc level of rumen contents was measured through cautery in ICP-MS (Sineo, MDS-10).

\section{Analysis of haematological parameters}

Red blood cells (RBCs), white blood cells (WBCs), haematocrit (Hct) values, and WBC types were determined whereas enzyme-linked immunosorbent assay (ELISA) analyzer was used to determine the haemoglobin $(\mathrm{Hb})$ amount with Drabkin's method spectrophotometrically (Fairbanks and Klee, 1987).
Analysis of some biochemical parameters in whole blood and plasma

Plasma urea nitrogen, glucose and cholesterol levels were measured by ELISA analyzer (Thermo Scientific, Multiskan FC, Finland) using commercial kit (Human, Germany Cat No: 12013, 13002, 12021). In blood samples, serum malondialdehyde (MDA), serum antioxidative activity (AOA) and glutathione (GSH) were determined by using the methods reported by Draper and Hardley (1990), Koracevic et al. (2001) and Beutler et al. (1963), respectively. Serum and tissue zinc levels (liver, kidney, pancreas, and mohair) were measured through cautery in ICP-MS (Agilent Technologies, ASX-500, Model No. 63286A)

\section{Statistical analysis}

Statistical analysis was performed using SPSS version 16.0 software. In terms of the levels of parameters evaluated in the study, ANOVA test was used to determine the significance level of the difference between the mean values of the groups, whereas t-test was applied to reveal the in-group difference with $\mathrm{p}<0.05$.

\section{RESULTS}

No significant $(\mathrm{p}>0.05)$ difference was observed between the groups with zinc supplementation of 500 ppm, $750 \mathrm{ppm}$, and $1000 \mathrm{ppm}$ on the live weight of goats (Table III).

Table III.- Effect of different levels of zinc on live weights of goats $(\mathrm{kg})(\mathrm{n}=6, \pm$ SEM).

\begin{tabular}{lccccc}
\hline $\begin{array}{l}\text { Sampling } \\
\text { time }\end{array}$ & $\begin{array}{c}\mathbf{0} \\
\mathbf{p p m}\end{array}$ & $\begin{array}{c}\mathbf{5 0 0} \\
\mathbf{p p m}\end{array}$ & $\begin{array}{c}\mathbf{7 5 0} \\
\mathbf{p p m}\end{array}$ & $\begin{array}{c}\mathbf{1 0 0 0} \\
\mathbf{p p m}\end{array}$ & $\mathbf{p}$ \\
\hline 0 day & $34.98 \pm$ & $34.90 \pm$ & $34.90 \pm$ & $34.83 \pm$ & 0.999 \\
& 1.18 & 1.30 & 1.46 & 1.27 & \\
15 day & $35.10 \pm$ & $35.21 \pm$ & $35.23 \pm$ & $35.85 \pm$ & 0.989 \\
& 1.59 & 1.55 & 1.67 & 1.42 & \\
30 day & $35.71 \pm$ & $35.65 \pm$ & $35.45 \pm$ & $36.20 \pm$ & 0.992 \\
& 1.43 & 1.85 & 1.94 & 1.70 & \\
\hline
\end{tabular}

There was a significant difference $(p<0.001)$ between the control group and 1000 ppm group in terms of the WBC count measured from the samples obtained on the $30^{\text {th }}$ day of the study. Similarly, a significant difference $(p<0.01)$ was observed between the groups in terms of the $\mathrm{Hb}$ levels measured from the blood samples obtained on the $30^{\text {th }}$ day of the study in all supplemented groups as compared to control (Table IV). 
Table IV.- Effects of different concentrations of zinc on haematological parameters of goats $(\mathrm{n}=6, \pm \mathrm{SEM})$.

\begin{tabular}{|c|c|c|c|c|c|c|}
\hline & Sampling time (day) & O ppm & 500 ppm & 750 ppm & 1000 ppm & $\mathbf{p}$ \\
\hline \multirow{2}{*}{$\begin{array}{l}\text { Erythrocytes/RBC } \\
\left(10^{6} / \mathrm{mm}^{3}\right)\end{array}$} & 15 & $15.87 \pm 1.01 \dagger$ & $15.50 \pm 1.01$ & $15.67 \pm 0.51$ & $16.25 \pm 0.84$ & 0.951 \\
\hline & 30 & $12.72 \pm 0.37^{\mathrm{a}}$ & $14.85 \pm 0.28^{\mathrm{b}}$ & $15.46 \pm 0.47^{\mathrm{b}}$ & $16.18 \pm 0.42^{\mathrm{c}}$ & 0.000 \\
\hline \multirow[t]{2}{*}{ Haemoglobin (g/dl) } & 15 & $9.28 \pm 0.41$ & $8.79 \pm 0.35$ & $9.84 \pm 0.68$ & $10.45 \pm 0.68$ & 0.208 \\
\hline & 30 & $7.93 \pm 0.45^{\mathrm{c}}$ & $8.44 \pm 0.39^{\mathrm{bc}}$ & $9.36 \pm 0.21^{\mathrm{ab}}$ & $9.70 \pm 0.22^{\mathrm{a}}$ & 0.004 \\
\hline \multirow[t]{2}{*}{ Haematocrit(\%) } & 15 & $24.83 \pm 1.35$ & $25.33 \pm 1.40$ & $26.66 \pm 1.35$ & $27.16 \pm 1.13$ & 0.567 \\
\hline & 30 & $24.66 \pm 1.14$ & $25.00 \pm 0.89$ & $25.83 \pm 1.27$ & $25.50 \pm 0.67$ & 0.856 \\
\hline \multirow{2}{*}{$\begin{array}{l}\text { Leukocytes }\left(10^{3 /}\right. \\
\left.\mathrm{mm}^{3}\right)\end{array}$} & 15 & $10.50 \pm 0.58$ & $10.80 \pm 0.10$ & $10.86 \pm 0.10$ & $10.76 \pm 0.92$ & 0.989 \\
\hline & 30 & $8.90 \pm 0.44$ & $9.70 \pm 0.38$ & $9.62 \pm 0.90$ & $9.72 \pm 0.85$ & 0.809 \\
\hline \multirow[t]{2}{*}{ Neutrophils (\%) } & 15 & $31.83 \pm 2.16 \dagger$ & $26.50 \pm 2.62$ & $33.16 \pm 1.37$ & $32.50 \pm 1.99$ & 0.129 \\
\hline & 30 & $26.16 \pm 1.24^{b}$ & $32.83 \pm 2.12^{\mathrm{ab}}$ & $30.00 \pm 2.78^{b}$ & $36.83 \pm 2.34^{\mathrm{a}}$ & 0.018 \\
\hline \multirow[t]{2}{*}{ Lymphocytes (\%) } & 15 & $65.66 \pm 1.90 \dagger$ & $70.50 \pm 2.47$ & $63.50 \pm 1.38$ & $65.33 \pm 2.04$ & 0.113 \\
\hline & 30 & $71.83 \pm 1.16^{\mathrm{a}}$ & $66.33 \pm 2.04^{\mathrm{b}}$ & $68.66 \pm 2.88^{\mathrm{ab}}$ & $61.33 \pm 2.45^{\mathrm{b}}$ & 0.023 \\
\hline \multirow[t]{2}{*}{ Monocytes (\%) } & 15 & $0.40 \pm 0.24$ & $0.83 \pm 0.30$ & $1.16 \pm 0.16$ & $0.50 \pm 0.22$ & 0.140 \\
\hline & 30 & $0.50 \pm 0.22$ & $0.33 \pm 0.21$ & $0.83 \pm 0.30$ & $0.33 \pm 0.21$ & 0.434 \\
\hline \multirow[t]{2}{*}{ Eosinophils (\%) } & 15 & $1.50 \pm 0.22$ & $1.13 \pm 0.16$ & $1.33 \pm 0.33$ & $1.33 \pm 0.42$ & 0.619 \\
\hline & 30 & $1.00 \pm 0.25$ & $0.73 \pm 0.21$ & $0.83 \pm 0.21$ & $1.00 \pm 0.25$ & 0.076 \\
\hline \multirow[t]{2}{*}{ Basophils (\%) } & 15 & $0.66 \pm 0.33$ & $0.50 \pm 0.22$ & $0.83 \pm 0.30$ & $0.33 \pm 0.21$ & 0.612 \\
\hline & 30 & $0.33 \pm 0.21$ & $0.26 \pm 0.16$ & $0.26 \pm 0.16$ & $0.26 \pm 0.16$ & 0.883 \\
\hline
\end{tabular}

a,b,c, The difference between the mean values of different letters in the same order is statistically significant. The difference between the same groups on the $15^{\text {th }}$ and $30^{\text {th }}$ days is significant. $\uparrow, \mathrm{P}<0.05$; $\dagger, \mathrm{P}<0.01$; $\dagger \dagger, \mathrm{P}<0.001$. RBC, Red blood cells.

No significant difference $(p>0.05)$ was found between the groups in terms of plasma cholesterol level, glucose and AOA levels measured from the blood samples obtained on the $15^{\text {th }}$ and $30^{\text {th }}$ day of the study (Table V).

In samples obtained on the $30^{\text {th }}$ day of the study, there was no change in 500 ppm group in terms of plasma urea nitrogen level compared to the control group, however, it was seen to increase $(\mathrm{p}<0.05)$ in $750 \mathrm{ppm}$ and 1000 ppm groups (Table V). Similarly, no significant difference $(p<0.01)$ was observed between the groups in terms of plasma GSH levels measured from the samples obtained on the $30^{\text {th }}$ day (Table V). There was a significant difference $(p<0.001)$ between the groups in terms of whole blood MDA levels measured from the samples obtained on the $15^{\text {th }}$ day of the study and a decrease was observed in $500 \mathrm{ppm}$ and $750 \mathrm{ppm}$ groups compared to control group and $1000 \mathrm{ppm}$ group (Table V). There was a significant decrease $(p<0.01)$ in the MDA levels of the experiment groups measured from the samples obtained on the $30^{\text {th }}$ day of the study, compared to the control group (Table V). Zinc level measured from the samples obtained on the $30^{\text {th }}$ day of the study was found to be higher in experimental groups than the control group $(p<0.05)$. The comparison of zinc levels measured from the samples obtained on the $15^{\text {th }}$ and $30^{\text {th }}$ day revealed that the zinc levels of the experimental groups were found to be higher $(p<0.01)$ on the $30^{\text {th }}$ day (Table V).

There was no difference ( $p>0.05)$ between the groups in terms of $\mathrm{pH}$ values of rumen content obtained at the $15^{\text {th }}$ and $30^{\text {th }}$ day of the study (Table VI). Measurements made on the rumen content samples obtained at the $15^{\text {th }}$ day revealed that there was a decrease $(p>0.01)$ in the ammonia nitrogen in the groups supplemented with zinc, compared to the control group. However, measurements made on the rumen samples taken at the $30^{\text {th }}$ day revealed that there was no difference between the control group and $500 \mathrm{ppm}$ group in terms of the ammonia nitrogen levels but there was a decrease in $750 \mathrm{ppm}$ group and $1000 \mathrm{ppm}$ group which was not significant $(\mathrm{p}<0.01)$. A significant difference was found between the groups in terms of the rumen protozoa count measured from the rumen content sample obtained on the $30^{\text {th }}$ day compared to the control group, there was a decrease in $500 \mathrm{ppm}, 750 \mathrm{ppm}$, and $1000 \mathrm{ppm}$ groups and this decrease was found to be similar in $750 \mathrm{ppm}$ and 1000 ppm groups $(\mathrm{p}<0.001)$. The rumen zinc level of the rumen content sample obtained on the $15^{\text {th }}$ and $30^{\text {th }}$ days was found to be significantly higher $(p<0.05)$ in the 1000 ppm group compared to the control group (Table VI).

The level of zinc in the liver tissues was found to be significantly higher $(\mathrm{p}<0.05)$ in $750 \mathrm{ppm}$ and $1000 \mathrm{ppm}$ groups than the control group (Table VII). There was no change in the groups in terms of copper levels, however, 
these levels were found to be significantly higher $(\mathrm{p}<0.05)$ in the kidney tissues of experimental groups compared to the control group. It was determined that there was a dosedependent increase $(p<0.05)$ in the iron levels in the liver tissue of $750 \mathrm{ppm}$ group compared to the control group (Table VII). A significant increase $(\mathrm{p}<0.05)$ was observed in the iron level in the mohair tissue of the 500ppm group compared to the control group (Table VII).

Table V.- Effects of different concentrations of zinc on the plasma cholesterol, glucose, urea-N, AOA, whole blood GSH, MDA and serum $\mathrm{Zn}, \mathrm{Cu}$ and Fe levels in goats $(\mathrm{n}=6, \pm \mathrm{SEM})$.

\begin{tabular}{|c|c|c|c|c|c|c|}
\hline & Sampling time & O ppm & 500 ppm & $750 \mathrm{ppm}$ & 1000 ppm & $\mathbf{p}$ \\
\hline \multirow{2}{*}{$\begin{array}{l}\text { Cholesterol } \\
(\mathrm{mg} / \mathrm{dl})\end{array}$} & 15 day & $44.21 \pm 6.30$ & $42.16 \pm 1.79$ & $39.29 \pm 3.96$ & $42.38 \pm 6.99$ & 0.926 \\
\hline & 30 day & $40.42 \pm 5.18$ & $46.27 \pm 5.33$ & $52.48 \pm 5.90$ & $40.95 \pm 8.34$ & 0.513 \\
\hline \multirow[t]{2}{*}{ Glucose (mg / dl) } & 15 day & $61.52 \pm 4.72$ & $46.16 \pm 5.09$ & $54.48 \pm 2.77$ & $50.66 \pm 3.92$ & 0.341 \\
\hline & 30 day & $48.59 \pm 2.44$ & $47.45 \pm 4.60$ & $48.85 \pm 2.77$ & $47.45 \pm 5.55$ & 0.287 \\
\hline \multirow[t]{2}{*}{ Urea-N (mg / dl) } & 15 day & $19.23 \pm 1.04$ & $15.31 \pm 0.80 \dagger$ & $16.09 \pm 1.05 \dagger$ & $17.57 \pm 1.07 \dagger$ & 0.059 \\
\hline & 30 day & $17.88 \pm 1.45^{\mathrm{b}}$ & $21.93 \pm 1.15^{\mathrm{ab}}$ & $24.50 \pm 1.58^{\mathrm{a}}$ & $25.38 \pm 1.96^{\mathrm{a}}$ & 0.013 \\
\hline \multirow[t]{2}{*}{$\mathrm{AOA}(\mathrm{mmol} / \mathrm{L})$} & 15 day & $6.57 \pm 0.69$ & $6.53 \pm 052$ & $6.28 \pm 0.29$ & $7.11 \pm 0.68$ & 0.776 \\
\hline & 30 day & $7.63 \pm 0.79$ & $7.96 \pm 043$ & $6.84 \pm 0.39$ & $6.93 \pm 0.38$ & 0.395 \\
\hline \multirow[t]{2}{*}{$\mathrm{GSH}(\mu \mathrm{mol} / \mathrm{L})$} & 15 day & $13.41 \pm 0.47 \dagger$ & $15.27 \pm 1.24$ & $16.07 \pm 0.64$ & $15.35 \pm 0.82$ & 0.182 \\
\hline & 30 day & $9.68 \pm 0.87^{b}$ & $17.75 \pm 2.42^{\mathrm{a}}$ & $14.29 \pm 0.60^{\mathrm{a}}$ & $15.62 \pm 0.95^{\mathrm{a}}$ & 0.005 \\
\hline \multirow[t]{2}{*}{ MDA (nmol / L) } & 15 day & $4.33 \pm 0.15^{\mathrm{a} \dagger \dagger}$ & $3.02 \pm 0.10^{c} \uparrow \dagger \dagger$ & $3.57 \pm 0.21^{\mathrm{b} \dagger \dagger}$ & $4.29 \pm 0.12^{\mathrm{a} \dagger \dagger \dagger}$ & 0.000 \\
\hline & 30 day & $6.26 \pm 0.32^{\mathrm{a}}$ & $5.13 \pm 0.12^{\mathrm{b}}$ & $5.27 \pm 0.21^{\mathrm{b}}$ & $5.30 \pm 0.14^{\mathrm{b}}$ & 0.005 \\
\hline \multirow[t]{3}{*}{$\mathrm{Zn}(\mu \mathrm{g} / \mathrm{dl})$} & 0 day & $98.32 \pm 7.2$ & $102.41 \pm 11.3$ & $96.00 \pm 2.31$ & $108.33 \pm 8.23$ & 0.990 \\
\hline & 15 day & $60.05 \pm 7.13$ & $64.31 \pm 8.42 \dagger \dagger$ & $68.15 \pm 12.77 \dagger \dagger$ & $86.50 \pm 11.75 \dagger \dagger$ & 0.659 \\
\hline & 30 day & $89.22 \pm 5.54^{\mathrm{c}}$ & $119.91 \pm 4.61^{\mathrm{b}}$ & $137.20 \pm 5.67^{\mathrm{ab}}$ & $151.44 \pm 2.65^{\mathrm{a}}$ & 0.040 \\
\hline \multirow[t]{2}{*}{$\mathrm{Cu}(\mu \mathrm{g} / \mathrm{dl})$} & 15 day & $42.22 \pm 18.64$ & $36.02 \pm 6.26$ & $41.64 \pm 6.60$ & $48.15 \pm 2.28 \dagger \dagger$ & 0.555 \\
\hline & 30 day & $42.58 \pm 6.61$ & $30.68 \pm 10.15$ & $39.03 \pm 8.09$ & $21.21 \pm 8.69$ & 0.340 \\
\hline \multirow[t]{2}{*}{$\mathrm{Fe}(\mu \mathrm{g} / \mathrm{dl})$} & 15 day & $2021.81 \pm 430.12$ & $2552.62 \pm 418.41$ & $2819.91 \pm 350.48$ & $3000.62 \pm 120.82$ & 0.248 \\
\hline & 30 day & $3168.52 \pm 263.13$ & $3153.13 \pm 842.15$ & $2444.93 \pm 411.54$ & $2586.54 \pm 630.53$ & 0.480 \\
\hline
\end{tabular}

a,b,c, The difference between the mean values of different letters in the same order is statistically significant. The difference between the same groups on the $15^{\text {th }}$ and $30^{\text {th }}$ days is significant. $\dagger, \mathrm{P}<0.05 ; \dagger+\mathrm{P}<0.01 ; \dagger \dagger, \mathrm{P}<0.001$. AOA, Antioxidant activity; GSH, Glutathione; MDA, Malondialdehyde; $\mathrm{Zn}$, Zinc; $\mathrm{Cu}$, Copper; Fe, Iron.

Table VI.- Effects of different concentrations of zinc on rumen fluids, number of protozoa, pH, ammonia nitrogen, $\mathrm{Zn}, \mathrm{Cu}$ and $\mathrm{Fe}$ in goats $(\mathrm{n}=6, \pm \mathrm{SEM})$.

\begin{tabular}{llccccc}
\hline & Sampling time & $\mathbf{0 ~ p p m}$ & $\mathbf{5 0 0} \mathbf{~ p p m}$ & $\mathbf{7 5 0} \mathbf{~ p p m}$ & $\mathbf{1 0 0 0} \mathbf{~ p p m}$ & P \\
\hline $\mathrm{pH}$ & 15 day & $6.92 \pm 0.10$ & $6.96 \pm 0.03$ & $6.80 \pm 0.06$ & $6.91 \pm 0.06$ & 0.479 \\
& 30 day & $6.87 \pm 0.04$ & $7.00 \pm 0.05$ & $6.76 \pm 0.07$ & $6.93 \pm 0.03$ & 0.056 \\
Ammonia nitrogen & 15 day & $15.16 \pm 0.51^{\mathrm{a}}$ & $12.85 \pm 0.64^{\mathrm{b}}$ & $12.31 \pm 0.35^{\mathrm{b}}$ & $11.19 \pm 0.67^{\mathrm{b}}$ & 0.001 \\
$(\mathrm{mg} / \mathrm{dl})$ & 30 day & $15.37 \pm 0.98^{\mathrm{ab}}$ & $13.21 \pm 1.40^{\mathrm{b}}$ & $12.29 \pm 0.53^{\mathrm{c}}$ & $9.18 \pm 1.02^{\mathrm{d}}$ & 0.003 \\
$\mathrm{Number}$ of protozoa & 15 day & $394.16 \pm 16^{\mathrm{a}}$ & $345.00 \pm 42^{\mathrm{a}}$ & $260.14 \pm 21^{\mathrm{b}+\dagger \dagger}$ & $247.08 \pm 24^{\mathrm{b}} \dagger \dagger$ & 0.003 \\
$\left(10^{3} / \mathrm{ml}\right)$ & 30 day & $375.27 \pm 25^{\mathrm{a}}$ & $266.53 \pm 12^{\mathrm{b}}$ & $205.83 \pm 21^{\mathrm{c}}$ & $186.11 \pm 15^{\mathrm{c}}$ & 0.000 \\
$\mathrm{Zn}(\mu \mathrm{g} / \mathrm{ml})$ & 15 day & $0.77 \pm 0.13^{\mathrm{b}}$ & $1.04 \pm 0.20^{\mathrm{ab}}$ & $1.22 \pm 0.26^{\mathrm{ab}}$ & $1.57 \pm 0.16^{\mathrm{a}}$ & 0.048 \\
& 30 day & $0.96 \pm 0.08^{\mathrm{b}}$ & $1.12 \pm 0.19^{\mathrm{ab}}$ & $1.35 \pm 0.17^{\mathrm{ab}}$ & $1.51 \pm 0.11^{\mathrm{a}}$ & 0.037 \\
$\mathrm{Cu}(\mu \mathrm{g} / \mathrm{ml})$ & 15 day & $0.30 \pm 0.08$ & $0.32 \pm 0.09 \dagger \dagger \dagger$ & $0.45 \pm 0.10 \dagger \dagger$ & $0.40 \pm 0.04 \dagger \dagger \dagger$ & 0.636 \\
$\mathrm{Fe}(\mu \mathrm{g} / \mathrm{ml})$ & 30 day & $0.51 \pm 0.12^{\mathrm{b}}$ & $0.64 \pm 015^{\mathrm{b}}$ & $0.87 \pm 0.08^{\mathrm{ab}}$ & $1.38 \pm 0.03^{\mathrm{a}}$ & 0.034 \\
& 15 day & $1.81 \pm 0.11^{\mathrm{a}}$ & $1.33 \pm 0.11^{\mathrm{ab}}$ & $1.50 \pm 0.14^{\mathrm{ab}}$ & $0.83 \pm 0.28^{\mathrm{b}} \dagger \dagger$ & 0.038 \\
\hline
\end{tabular}

a,b,c, The difference between the mean values of different letters in the same order is statistically significant. The difference between the same groups on the $15^{\text {th }}$ and $30^{\text {th }}$ days is significant. $\dagger, \mathrm{P}<0.05 ; \dagger \uparrow, \mathrm{P}<0.01 ; \dagger \dagger, \mathrm{P}<0.001$. Zn, Zinc; $\mathrm{Cu}$, Copper; Fe, Iron. 
Table VII.- Effects of different concentrations of zinc on accumulation of zinc (ppm) in different rgans of goats $(\mathrm{n}=6$, \pm SEM).

\begin{tabular}{|c|c|c|c|c|c|c|}
\hline & Tissue & 0 ppm & 500 ppm & 750 ppm & 1000 ppm & $\mathbf{P}$ \\
\hline \multirow{4}{*}{$\begin{array}{l}\mathrm{Zn} \\
(\mathrm{ppm})\end{array}$} & Liver & $77.95 \pm 7.75^{b}$ & $93.13 \pm 7.76^{\mathrm{ab}}$ & $109.52 \pm 8.23^{\mathrm{a}}$ & $114.03 \pm 12.06^{\mathrm{a}}$ & 0.043 \\
\hline & Kidney & $33.17 \pm 2.76$ & $26.86 \pm 2.63$ & $25.56 \pm 1.40$ & $28.65 \pm 2.58$ & 0.161 \\
\hline & Pancreas & $45.35 \pm 1.63$ & $45.18 \pm 2.47$ & $49.19 \pm 3.04$ & $48.96 \pm 1.95$ & 0.461 \\
\hline & Mohair & $120.90 \pm 10.80$ & $125.70 \pm 3.06$ & $137.72 \pm 15.39$ & $156.30 \pm 36.90$ & 0.608 \\
\hline \multirow{4}{*}{$\begin{array}{l}\mathrm{Cu} \\
(\mathrm{ppm})\end{array}$} & Liver & $0.66 \pm 0.10$ & $0.44 \pm 0.17$ & $0.50 \pm 0.12$ & $0.10 \pm 0.05$ & 0.305 \\
\hline & Kidney & $8.48 \pm 0.73^{\mathrm{a}}$ & $6.30 \pm 0.69^{b}$ & $6.63 \pm 0.34^{\mathrm{b}}$ & $6.85 \pm 0.31^{\mathrm{b}}$ & 0.050 \\
\hline & Pancreas & $1.79 \pm 0.14$ & $1.50 \pm 0.05$ & $1.80 \pm 0.17$ & $1.92 \pm 0.16$ & 0.220 \\
\hline & Mohair & $7.84 \pm 0.46$ & $10.01 \pm 1.08$ & $9.04 \pm 0.48$ & $8.00 \pm 0.34$ & 0.103 \\
\hline \multirow{4}{*}{$\begin{array}{l}\mathrm{Fe} \\
(\mathrm{ppm})\end{array}$} & Liver & $255.67 \pm 29.28^{b}$ & $300.50 \pm 43.71^{\mathrm{ab}}$ & $390.19 \pm 46.40^{\mathrm{a}}$ & $231.79 \pm 28.54^{\mathrm{b}}$ & 0.038 \\
\hline & Kidney & $92.78 \pm 6.87$ & $99.80 \pm 16.43$ & $85.23 \pm 8.08$ & $93.41 \pm 6.66$ & 0.804 \\
\hline & Pancreas & $29.68 \pm 3.03$ & $33.38 \pm 2.36$ & $36.57 \pm 1.88$ & $30.52 \pm 3.50$ & 0.310 \\
\hline & Mohair & $1073.00 \pm 236.70^{b}$ & $1702.90 \pm 338.50^{\mathrm{a}}$ & $1180.10 \pm 158.90^{\mathrm{ab}}$ & $738.40 \pm 13.42^{\mathrm{b}}$ & 0.050 \\
\hline
\end{tabular}

a,b, The difference between the mean values of different letters in the same order is statistically significant.

\section{DISCUSSION}

The $\mathrm{Zn}$ supplementation is known to have positive effect on performance parameters in goats (Malcolm-Callis et al., 2000). In the present study, no difference was found between the groups in terms of live weights recorded on the same days. This result did not match with the studies by Malcolm-Callis et al. (2000) who observed that 100 ppm zinc supplementation reduces feed consumption and live weight and by Aksoy et al. (2002) observed that 500 mg zinc supplementation once a week per animal increases the live weight in lambs. However, it is compatible with the studies where the feed of the goats was supplemented with 250 ppm zinc (Eryavuz et al., 2002), feed of the sheep was supplemented with $1000 \mathrm{ppm}$ zinc (Bonhomme et al., 1980) and 2100 ppm zinc (Henry et al., 1997), and feed of the cattle was supplemented with $1000 \mathrm{ppm}$ zinc (Miller et al., 1989; Froestchel et al., 1990). In these studies, it was demonstrated that zinc supplementation had no effect on feed consumption and live weight. As a matter of fact, it has been documented that zinc supplementation to the feed of ruminant animals fed with feed containing optimum zinc does not have an effect on live weight (White et al., 1994). This also indicates that the $1000 \mathrm{ppm}$ zinc supplementation has no negative effect on live weight and feed consumption in goats, as in cattle (Miller et al., 1989; Froestchel et al., 1990) and sheep (Henry et al., 1997). Long-term studies on goats may reveal the effect of high zinc supplementation on the feeding performance.

Zinc has been claimed to be associated with erythrocyte and haemoglobin production, and male goats living at high altitudes with increased erythrocytosis and blood haemoglobin levels have been emphasized to have higher serum zinc levels (Gonzales et al., 2011). Similarly in the studies reported by Dönmez and Keskin (1999) that the $250 \mathrm{ppm}$ and $500 \mathrm{ppm}$ by Sobhanirad and Naserian (2012) zinc supplementation in goats and cattle increase the $\mathrm{RBC}$ and $\mathrm{Hb}$ levels, a significant increase was found in the $\mathrm{RBC}$ and $\mathrm{Hb}$ levels measured from the samples obtained on the $30^{\text {th }}$ day of the study in the zinc supplemented groups compared to the control group. Our results were also in accordance with the studies reported by Sobhanirad and Naserian (2012) that 500 ppm zinc supplementation to the ration of dairy cows and $250 \mathrm{ppm}$ zinc supplementation to the ration of goats by Dönmez and Keskin (1999) increased the RBC and $\mathrm{Hb}$ levels. However, in a study, reported by Miller et al. (1989) that 1000 ppm zinc supplementation to the feed of cattle has no effects on the relevant parameters which were not compatible with our results. In a study by Ott et al. (1966), it was reported that the $\mathrm{Hb}$ and Hct levels of the lambs consuming $4000 \mathrm{ppm}$ and $6000 \mathrm{ppm}$ zinc, was increased, which was attributed to the haemoconcentration. In the present study, $\mathrm{Hb}$ levels were seen to increase but no change was observed in Hct value, indicating that the $1000 \mathrm{ppm}$ zinc supplementation to the feed of goats had no negative effects such as haemoconcentration. In a study by Dönmez and Keskin (1999), they fed Angora goats with the control ration containing $35 \mathrm{ppm}$ and a treatment ration supplemented with $250 \mathrm{ppm}$ zinc for six months and declared that there was no change in the $\mathrm{RBC}, \mathrm{Hb}$, and Hct levels until the third month. However, they further observed that there was a decrease in the relevant values of the control group during the last sampling period of the study and they attributed this to the restriction of the 
movement of animals due to the pasture conditions. Ülger and Coşkun (2003) reported in their study that the amount of zinc in the RBCs is approximately ten times higher than the zinc amount in the plasma because RBCs are rich in enzymes such as zinc-containing carbonic anhydrase. Considering this fact, adding zinc to the feed of goats with a smaller RBC diameter and a higher number of RBC (Reece and Swenson, 2008), compared to the sheep, can be said to have a positive effect on the number of RBC and the amount of $\mathrm{Hb}$ and to have the ability to prevent the decrease in the number of $\mathrm{RBC}$ due to movement restriction.

In the present study, 500-1000 ppm zinc supplementation resulted in no difference between the groups in terms of plasma total cholesterol levels measured from the samples obtained on the $15^{\text {th }}$ and $30^{\text {th }}$ days. It is stated that zinc has a structural and functional characteristic for lipid enzymes and lipid metabolism is impaired in the case of zinc deficiency (Li et al., 2013). Furthermore, high zinc intake reduces the lecithin-cholesterol acyltransferase enzyme activity as well as cholesterol, cholesterol esters, and plasma lipids. Indeed, the addition of $1000 \mathrm{ppm}$ zinc to the ration has been shown to reduce plasma cholesterol esters by $10 \%$ and $500-1000$ ppm zinc supplementation has been shown to reduce the cholesterol concentration by about $10 \%$ (Jenkins and Kramer, 1992). In a study by Malcolm-Callis et al. (2000), they added 20 ppm, 100 ppm, and $200 \mathrm{ppm}$ zinc sulphate to the rations of feeder cattle and found that this zinc sulphate supplementation did not change the serum cholesterol levels. Similar to the findings of the present study, it was reported by Sobhanirad and Naserian (2012), that dairy cows with 500 ppm zinc did not change the total cholesterol level. On the other hand, in a study by Jenkins and Kramer (1992), in which 500 and $1000 \mathrm{ppm}$ zinc was added to the milk of the calves, plasma cholesterol levels of these calves were reported to decrease. In this context, the study results revealed that 500-1000 ppm zinc has no effect on the cholesterol level.

No significant difference was observed between the groups in terms of the glucose level measured from the blood samples obtained on the $15^{\text {th }}$ and $30^{\text {th }}$ days. Avc1 et al. (2013) added $250 \mathrm{ppm}$ zinc to the feed of different breeds of sheep for a month and found that plasma glucose level did not change compared to control groups. Similarly, in other studies of Angora goat and calves by Puchala et al. (1999) and Mandal and Dass (2010), zinc added to the ration was reported to have no effect on the plasma glucose level.

It is known that the plasma urea nitrogen level in ruminants is highly influenced by the amount and type of protein in the ration and by the deamination of amino acids in the liver (Ayaşan, 2009). In the present study, the plasma urea nitrogen level did not change on the $15^{\text {th }}$ day of the study and a significant increase was observed in the $1000 \mathrm{ppm}$ group, in particular, on the $30^{\text {th }}$ day. This finding is similar with the study by Eryavuz et al. (2002) in which $250 \mathrm{ppm}$ zinc was supplemented to the ration of Angora goats and with another study conducted on two different sheep breeds (Avc1 et al., 2013). This effect can be explained by the fact that a high level of zinc reduces protein digestion by decreasing activation of rumen microorganisms and passage of more proteins into the lower digestive organs. Puchala et al. (1999) demonstrated that the addition of zinc did not change the plasma urea level. Similarly, in a study by Mandal and Dass (2010) in which $35 \mathrm{ppm}$ zinc was added to the feed of calves, it has been shown that the mean serum urea levels did not change on the $30^{\text {th }}$ day if the periods were not considered (but there was a significant increase in the total period average).

Reduction of MDA levels in experimental groups compared to the control group in our study is matching up with the antiperoxidative activity of zinc on lipids and the case where the zinc stabilizes the membrane structures by antagonizing redox active metals such as iron and copper (Shaheen and El-Fattah 1995). In contrary to our finding, in a study by Nagalakshmi et al. (2009) on lambs, $15 \mathrm{ppm}$ zinc supplemented to the basal ration was observed to be sufficient to protect the oxidantantioxidant balance and the addition of higher zinc (45 ppm) was declared to have no effect in terms of reducing the oxidative stress. In the literature, it was reported that zinc supplementation decreased MDA and elevated GSH, however, Avc1 et al. (2013) found that the change in the MDA and GSH levels were not significant in their study in which $250 \mathrm{ppm}$ zinc was added to the feed of different breed sheep. The findings of the present study are in line with the finding that the addition of zinc to the feed of sheep does not lead to a change in total AOA reported by Avc1 et al. (2013), whereas it is in contrary to the finding that AOA level increases in rats which are given feed with high zinc levels (Jing et al., 2007). The fact that there is no significant difference between the groups in terms of AOA level, which is an important indicator of oxidative stress, indicates that there is no feeding and environment causing oxidative stress in animals.

Serum zinc level was particularly determined in the formation of groups and was within normal limits which were $80-120 \mu \mathrm{g} / \mathrm{dL}$ (Altıntaş and Fidanc1, 1993). In the samples obtained on the $15^{\text {th }}$ day, serum zinc levels were under the normal limits, except for the 1000 ppm group. On the $30^{\text {th }}$ day sampling, serum zinc levels were found to be within the normal limits in control and 500 ppm groups, however, $750 \mathrm{ppm}$ and $1000 \mathrm{ppm}$ groups were found to 
have significantly higher serum zinc levels (Table V). In a study by Sobhanirad and Naserian (2012), 18 Holstein Friesians were divided into three groups; control, 500 ppm zinc sulphate and $500 \mathrm{ppm}$ zinc methionine and serum zinc levels measured at the end of the $15^{\text {th }}$ day were found as 133, 243 and $284 \mu \mathrm{g} / \mathrm{dL}$. Serum zinc levels were reported to be higher compared to the zinc sulphate similar to the results of the studies by Ott et al. (1966) and Stake et al. (1975).

In the present study, it was found that serum copper and iron levels were not affected by the supplementation. In a study by Aksoy et al. (2002) in which $500 \mathrm{mg}$ zinc oxide was administered orally to the lambs once a week for a total of 12 weeks, it was reported that serum copper levels significantly decreased and there was no change in iron levels. Our findings are similar with their findings in terms of iron levels, but contrary to in terms of copper levels. It has been further reported that the addition of 250 ppm zinc to the ration of the goats by Eryavuz et al. (2001), administration of $500 \mathrm{mg}$ zinc per goat daily by Pechova et al. (2009) and addition of $1000 \mathrm{ppm}$ zinc to the feed of cattle by Miller et al. (1989) have no effect on the copper levels and our findings are compatible with this.

The $\mathrm{pH}$ levels of the rumen samples obtained on the $15^{\text {th }}$ and $30^{\text {th }}$ day were found to be within the range of 6.767.00 , which was similar with the studies by Eryavuz et al. (2002) and Cecava et al. (1993) in which they observed that zinc supplementation had no effect on the rumen pH levels. Run et al. (2013) emphasized in their in vitro study that rumen $\mathrm{pH}$ levels did not change with the zinc supplementation. Contrary to this, Önder and Keçeci (2003) in their research on Merino breed sheep have suggested that the zinc decreases the rumen $\mathrm{pH}$ levels. In a study by Arelovich et al. (2000) on dairy cows, a similar reduction was observed and the reason for this reduction in $\mathrm{pH}$ was reported to be due to the high level of zinc inhibiting urea hydrolysis and reducing ammonia production.

The addition of high levels of zinc to the feed of ruminant animals has been reported to cause changes in rumen fermentation (Bonhomme et al., 1980; Arelovich et al., 2000; Bateman et al., 2004). In several studies, the addition of zinc to the feed of ruminants was reported to affect the number and function of rumen microorganisms and the level of ammonia was accordingly affected by this situation (Arelovich et al., 2000; Bateman et al., 2004). In the samples obtained on the $15^{\text {th }}$ and $30^{\text {th }}$ day, the level of ammonia nitrogen was found to decrease in the zincadded groups compared to the control group in the present study. It may be due to the ability of zinc to reduce the breakdown of amino acids and increases the post-ruminal transmission of the amino acid in the ration (Froetschel et al., 1990). This was compatible with the study by
Eryavuz et al. (2002) in which the addition of $250 \mathrm{ppm}$ zinc added to the feed of the Angora goats decreased the rumen ammonia nitrogen level. It has been reported that high levels of zinc in sheep affect the urea and nitrogen balance, while $860 \mathrm{ppm}$ zinc has significantly reduced the rate of $\mathrm{NH}_{3}$ formation (Arelovich et al., 1998). In a study by Mousa (2014) the reason for the effect of the addition of zinc on the ammonia level in rumen content of sheep and goats was reported to be due to the decrease in the release of ammonia from urine. On the other hand, in another in vitro study, $40 \mathrm{ppm}$ zinc addition to the feed containing $37.60 \mathrm{ppm}$ did not change the ammonia levels (Run et al., 2013) which can be attributed to the low dosage use.

Froetschel et al. (1990) reported that the addition of $1142 \mathrm{ppm}$ zinc reduced the number of protozoa, and Bonhomme (1990) observed that the addition of 500 ppm or 1000 ppm zinc may cause protonation by killing the protozoa in the rumen. Similar to these studies, it was found that the number of protozoa decreased due to the addition of a high amount of zinc to the feed and the highest decrease was observed in the group supplemented $1000 \mathrm{ppm}$ zinc. In an in vitro study, it was reported that the addition of zinc chloride to the rumen content of goats and sheep reduced the number of protozoa (Mousa, 2014). It has been demonstrated that rumen protozoa receive an excessive amount of zinc to their structure, even if they are toxic to themselves, and are therefore fragmented if there is too much zinc content in the environment because Rumen protozoa cannot control consumption in contrast to bacteria (Bonhomme, 1990). Considering the fact that faunated animals have lower rumen ammonia levels than defaunated animals (Eryavuz et al., 2002), the low number of protozoa in goats consuming a high amount of zinc may lead to a decrease in the rumen ammonia level. The findings obtained in this study show that zinc can be used to transfer the benefits obtained from defaunation to field conditions (Eryavuz, 2000).

The zinc levels of rumen fluid in the zinc-supplemented groups were found to be higher than those in the control group and these high levels were observed to be significant in the group supplemented with 1000 ppm zinc $(\mathrm{p}<0.05)$. This result was similar with the study by Eryavuz et al. (2002) who reported that zinc rumen fluid added to the feed of goat increased the zinc levels. In an in vitro study by Run et al. (2013) it has been documented that as the zinc level added to the rumen content increases, the zinc level measured in the rumen content also increases. In the present study, the rumen fluid zinc levels of the animals in the control group were within the rumen fluid zinc levels (0.20-1.00 $\mu \mathrm{g} / \mathrm{mL})$, which have been reported to provide optimum microbial growth in feed containing $50 \mathrm{ppm}$ zinc in the dry matter (Reid et al., 1987). The rumen fluid zinc 
levels of the groups supplemented with zinc were below the level $(2.35 \mu \mathrm{g} / \mathrm{mL})$ reported by Kennedy et al. (1993) in cattle fed with $920 \mathrm{ppm}$ zinc but above the level (1.12 $\mu \mathrm{g} / \mathrm{mL}$ ) reported in Angora goats fed with $250 \mathrm{ppm}$ zinc (Eryavuz et al., 2002). Similar to rumen fluid zinc levels, the addition of zinc to the feed increased the copper levels in the rumen content and the increase in the rumen content of the goats given $1000 \mathrm{ppm}$ zinc supplementation was found to be significant $(p<0.05)$. The reason for this result can be attributed to the decrease in the number of protozoa in the rumen. In fact, Ivan et al. (1992) reported that the level and absorption of copper in the rumen fluid increased due to the decrease in the number of protozoa in the rumen.

Ruminants show high tolerance towards the high amount of zinc intake because zinc is a mineral with low toxicity (Suttle, 2010). In the present study, the effects of high dietary zinc on the zinc, copper and iron levels in mohair, liver, kidney, and pancreas samples were also investigated and a significant increase was observed in zinc levels with the addition of $750 \mathrm{ppm}$ and $1000 \mathrm{ppm}$ zinc in liver samples. In mohair samples, zinc levels were observed to increase depending on the amount of addition, but this increase was not statistically significant. In the kidney samples, a significant decrease was found in the copper levels of groups given high zinc supplementation, but a higher amount of zinc supplementation was found not to contribute to this decrease. Liver iron levels were found to increase significantly with the addition of 750 ppm zinc, however, there was no such increase in the 1000 ppm zinc addition in the liver. In a study by Eryavuz et al. (2002) after the addition of $250 \mathrm{ppm}$ zinc to the feed of the goats, an increase in the mohair zinc levels was observed four months later. In line with these findings, there was a nonsignificant increase in the mohair zinc levels obtained in the present study. Compatible with the study by Sandoval et al. (1997) who described that 700 ppm, $1400 \mathrm{ppm}$, and $2100 \mathrm{ppm}$ zinc supplementation increased the level of liver zinc depending on the amount of addition in sheep, the addition of zinc to the feed was found to increase the liver zinc levels in the present study. However, an increase in the pancreas and kidney tissue was also reported in the same study. The difference between this and the present study can be attributed to differences in animal species and the amount of zinc additions used in trials. The results obtained from this study showed that high zinc supplementation reduces the storage of copper in the liver and kidney in goats fed with high zinc supplement for 30 days but increases iron storage in mohair and liver.

\section{CONCLUSION}

Zinc has influenced the WBC count, Hb concentration, blood urea nitrogen, MDA levels, and zinc availability in supplemented groups. Similarly, zinc supplementation decreased rumen ammonia nitrogen, rumen protozoa, $\mathrm{Cu}$ concentration in kidney tissue and increases $\mathrm{Fe}$ in mohair up to $500 \mathrm{ppm}$. It is concluded that goats can tolerate $\mathrm{Zn}$ level even up to $750 \mathrm{ppm}$ in the diet.

\section{ACKNOWLEDGMENT}

This study, supported by TÜBİTAK (1130164), is summarized from the PhD thesis of Elmas Ulutas.

\section{Statement of conflict of interest}

The authors have declared no conflict of interest.

\section{REFERENCES}

Aksoy, G., Şahin, T., Çimtay, İ. and Arserim-Kaya, N.B., 2002. Kuzularda çinko oksit uygulamalarının bazı biyokimyasal parametreler ve canlı ağırlık kazancı üzerine etkileri. Turk. J. Vet. Anim. Sci., 26: 85-90.

Altintaş, A. and Fidanci, U., 1993. Evcil hayvanlarda ve insanda kanın biyokimyasal normal değerleri. Ankara Üniv. Vet. Fak. Derg., 40: 173-186. https:// doi.org/10.1501/Vetfak_0000001487

Anonymous, 2012. Minerals. Texas Agricultural Extension Service, Uvalde. Available at: http:// animalscience.tamu.edu/wp-content/uploads/ sites/14/2012/04/nutrition-minerals.pdf (accessed on 04 November, 2019).

Arelovich, H.M., 1998. Effects of zinc and manganese on digestion, ruminal and blood parameters of cattle fed prairie hay. $\mathrm{Ph} \mathrm{D}$ thesis, Oklahoma State University, Stillwater.

Arelovich, H.M., Owens, F.N., Horn, G.W. and Vizcarra, J.A., 2000. Effects of supplemental zinc and manganese on ruminal fermentation, forage intake, and digestion by cattle fed prairie hay and urea. J. Anim. Sci., 78: 2972-2979. https://doi. org/10.2527/2000.78112972x

Avci, G., Küçükkurt, İ., Kontaş, T., Eryavuz, A. and Fidan, F., 2013. Farklı 1rk koyunlarda rasyona çinko ilave edilmesinin plazma leptin, insulin ve tiroid hormon düzeyleri ile bazı biyokimyasal parametreler üzerine etkisi. Ankara Üniv. Vet. Fak. Derg., 60: 1-5. https://doi.org/10.1501/ Vetfak_0000002545

Ayaşan, T., 2009. Süt ineklerinin beslenmesinde süt üre nitrojenin önemi. Gaziosmanpaşa Üniv. Zir. Fak. Derg., 26: 27-33.

Bateman, H.G., Williams, C.C., Gantt, D.T., Chung, Y.H., Beem, A.E., Stanley, C.C., Goodier, G.E., 
Hoyt, P.G., Ward, J.D. and Bunting, L.D., 2004. Effects of zinc and sodium monensin on ruminal degradation of lysine-HCl and liquid 2-hydroxy4-methylthiobutanoic acid. J. Dairy Sci., 87: 2571-2577. https://doi.org/10.3168/jds.S0022$0302(04) 73382-2$

Beutler, E., Duron, O. and Kelly, B.M., 1963. Improved method for the determination of blood gultathione. J. Lab. clin. Med., 61: 882-888.

Bonhomme, A., 1990. Rumen ciliates: Their metabolism and relationship with bacteria and their hosts. Anim. Feed Sci. Technol., 30: 203-266. https://doi. org/10.1016/0377-8401(90)90016-2

Bonhomme, A., Quintana, C. and Durand, M., 1980. Elektron microprobe analysis of zinc incorporation into rumen protozoa. J. Protozool., 27: 491497. https://doi.org/10.1111/j.1550-7408.1980. tb05405.x

Cecava, M.J., Hancock, D.L. and Parker, J.E., 1993. Effects of zinc-treated soybean meal on ruminal fermentation and intestinal amino acid flows in steers fed corn silage-based diets. J. Anim. Sci., 71: 34233431. https://doi.org/10.2527/1993.71123423x

Dönmez, N. and Keskin, E., 1999. Ankara keçilerinde rasyona çinko ilavesinin bazı hematolojik parametreler üzerine etkisi. Vet. Bil. Derg., 15: 125131.

Draper, H.H. and Hardley, M., 1990. Malondialdehyde determination as index of lipid peroxidation. Methods Enzymol., 186: 421-443. https://doi. org/10.1016/0076-6879(90)86135-I

Droke, E.A., Gengelbach, G.P. and Spears, J.W., 1998. Influence of level and source (inorganic vs organic) of zinc supplementation on immune function in growing lambs. Asian-Aust. J. Anim. Sci., 11: 139144. https://doi.org/10.5713/ajas.1998.139

Dubeuf, J.P., Morand-Fehr, P. and Rubino, R., 2004. Situation, changes and future of goat industry around the world. Small Rumin. Res., 51: 165-173. https://doi.org/10.1016/j.smallrumres.2003.08.007

Eryavuz, A., 2000. Defaunasyonun ruminantların sindirimine etkileri (Derleme). Hayv. Araş. Derg., 10: $78-84$.

Eryavuz, A., Altunok, V., Keskin, E. and Haliloğlu, S., 2001. Ankara keçilerinde rasyona çinko ilavesinin ve defaunasyonun bazı plazma mineral madde düzeylerine etkileri. Hayv. Araş. Derg., 11: 39.

Eryavuz, A., Durgun, Z. and Keskin, E., 2002. Faunalı ve faunasız Ankara keçilerinde rasyona çinko katılmasının bazı rumen ve kan metabolitleri ile tiftik verimi ve niteliğine etkileri. Turk. J. Vet. Anim. Sci., 26: 753-760.
Fairbanks, V.F. and Klee, G.G., 1987. Biochemical aspect of haematology. In: Fundamentals of clinical chemistry (ed. N.W. Tietz), $3^{\text {rd }}$ ed. Saunders, Philadelphia, pp. 803-804.

Froetschel, M.A., Martin, A.C., Amos, H.E. and Evans, J.J., 1990. Effects of zinc sulfate concentration and feeding frequency on ruminal protozoal numbers, fermentation patterns and amino acid passage in steers. J. Anim. Sci., 68: 2874-2884. https://doi. org/10.2527/1990.6892874x

Froetscher, K.R., Hauser, S. and Baumgartner, W., 2005. Zinc-responsive dermatosis in goats suggestive of hereditary malabsorption: Two field cases. Vet. Dermatol., 16: 269-275. https://doi.org/10.1111/ j.1365-3164.2005.00459.x

Farenzena, R., Kozloski, G.V., Gindri, M. and Stefanello, S., 2017. Minimum length of the adaptation and collection period in digestibility trials with sheep fed ad libitum only forage or forage plus concentrate. J. Anim. Physiol. Anim. Nutr., 101: 1057-1066. https://doi.org/10.1111/jpn. 12550

FAO, 2018. World food and agriculture statistical pocketbook. Food and Agriculture Organization, Rome, pp. 30.

FAO, 2019. Production of beeswax. Food and Agriculture Organization of the United Nations, FAO, Rome. Available at: http://www.fao.org/faostat/en/\#data/ QL/visualize (Accessed on 04 November, 2019).

Gonzoles, G.F., Tapia, V., Manuel, G., Rubio, J. and Gonzoles-Castañeda, C., 2011. High serum zinc and serum testosterone levels were associated with excessive erythrocytosis in men at high altitudes. Endocrine, 40: 472-480. https://doi.org/10.1007/ s12020-011-9482-1

Henry, P.R., Littell, R.C. and Ammerman, C.B., 1997. Effect of high dietary zinc concentration and length of zinc feeding on feed intake and tissue zinc concentration in sheep. Anim. Feed Sci. Technol., 66: 237-245. https://doi.org/10.1016/S03778401(96)01104-2

Ivan, M., Dayrell, M.S. and Hidiroglou, M., 1992. Effects of Bentonite and Monensin on selected elements in the stomach and liver of fauna-free and faunated sheep. J. Dairy Sci., 75: 201-208. https:// doi.org/10.3168/jds.S0022-0302(92)77754-6

Jenkins, K. and Kramer, J.K.G., 1992. Changes in lipid composition of calf tissues by excess dietary zinc. $J$. Dairy Sci., 75: 1313-1319. https://doi.org/10.3168/ jds.S0022-0302(92)77882-5

Jia, W., Jia, Z., Zhang, W., Wang, R., Runlian, W., Zhang, S. and Zhu, X., 2008. Effects of dietary zinc on performance, nutrient digestibility and 
plasma zinc status in Cashmere goats. Small Rumin. Res., 80: 68-72. https://doi.org/10.1016/j. smallrumres.2008.09.009

Jing, M.Y., Sun, J.Y., Sun, W., Qian, L.C. and Weng, X.Y., 2007. Effects of zinc on hepatic antioxidant systems and the mRNA expression levels assayed by cDNA micrarrays in rats. Annls Nutr. Metab., 51: 345-351. https://doi.org/10.1159/000107677

Kennedy, D.W., Craig, W.M. and Southern, L.L., 1993. Ruminal distribution of zinc in steers fed a polysaccharide-zinc complex or zinc oxide. J. Anim. Sci., 71: 1281-1287. https://doi. org/10.2527/1993.7151281x

Koracevic, D., Koracevic, G., Djordjevic, V., Andrejevic, S. and Cosic, V., 2001. Method for the measurement of antioxidant activity in human fluids. J. clin. Pathol., 54: 356-361. https://doi. org/10.1136/jcp.54.5.356

Kundu, MS., Kumar, A., Jeyakumar, S., Sunder, J., Kundu, A. and Sujatha, T., 2014. Effect of zinc supplementation on reproductive performance of Teressa goat. Vet. World, 7: 380-383. https://doi. org/10.14202/vetworld.2014.380-383

Li, X., Guan, Y., Shi, X., Ding, H., Song, Y., Li, C., Liu, R. and Liu, G., 2013. Effects of high zinc levels on the lipid synthesis in rat hepatocytes. Biol. Trace Elem. Res., 154: 97-102. https://doi.org/10.1007/ s12011-013-9702-z

Malcolm-Callis, K.J., Duff, G.C., Gunter, S.A., Kegley, E.B. and Vermeire, D.A., 2000. Effects of supplemental zinc concentration and source on performance, carcass characteristics, and serum values infinishing beef steers. J. Anim. Sci., 78: 28012808. https://doi.org/10.2527/2000.78112801x

Mallaki, M., Norouzian, M.A. and Khadem, A.A., 2015. Effect of organic zinc supplementation on growth, nutrient utilization, and plasma zinc status in lambs. Turk. J. Vet. Anim. Sci., 39: 75-80. https:// doi.org/10.3906/vet-1405-79

Mandal, G.P. and Dass, R.S., 2010. Haematobiochemical profile of crossbred calves supplemented with inorganic and organic source of zinc. Indian J. Anim. Res., 44: 197-200.

Miller, W.J., Amos, H.E., Gentry, R.P., Blackmon, D.M., Durrance, R.M., Crowe, C.T., Fielding, A.S. and Neathery, M.W., 1989. Long-term feeding of high zinc sulfate diets to lactating and gestating dairy cows. J. Dairy Sci., 72: 1499-1508. https:// doi.org/10.3168/jds.S0022-0302(89)79260-2

Mousa, S.A., 2014. Influence of in vitro addition of metal ions salts on rumen fermentation parameters and selected ruminal enzymes activity in sheep and goats. Life Sci. J., 11: 198-203.

Nagalakshmi, D., Dhanalakshmi, K. and Himabindu, D., 2009. Effects of dose and source of supplemental zinc on immune response and oxidative enzymes in lambs. Vet. Res. Commun., 33: 631-644. https://doi. org/10.1007/s11259-009-9212-9

NRC, 1980. Mineral tolerance of domestic animals. National Academy Press, National Research Council, Washington, D.C.

NRC, 2007. Nutrient requirements of small ruminants: Sheep, goats, cervids, and new world camelids, $6^{\text {th }}$ ed. National Academy Press, National Research Council, Washington, DC, pp. 384.

Önder, F. and Keçeci, T., 2003. Konya merinosu kuzularda rasyona çinko ve bakır ilavesinin bazı hematolojik parametrelere etkisi. Istanbul Üniv. Vet. Fak. Derg., 29: 33-41.

Ott, E.A, Smith, W.H., Harrington, B.B. and Becson, W.M., 1966. Zinc toxicity in ruminants. II. Effects of high levels of dietary zinc on gains feed consumption and feed efficiency of beef cattle. $J$. Anim. Sci., 25: 419-423. https://doi.org/10.2527/ jas 1966.252419x

Özdemir, M., Çinar, M., Haliloğlu, S. and Eryavuz, A., 2006. Effects of defaunation and dietary nitrogen source on sodium, potassium, iron and zinc in the rumen fluid, plasma and wool of lambs. Turk. J. Vet. Anim. Sci., 30: 367-373.

Pavlata, L., Chomat, M., Pechova, A., Misurova, L. and Dvorak, R., 2011. Impact of long-term supplementation of zinc and selenium on their content in blood and hair in goats. Vet. Med., 56: 63-74. https://doi.org/10.17221/1581-VETMED

Pechova, A., Misurova, L., Pavlata, L. and Dvorak, R., 2009. The influence of supplementation of different forms of zinc in goats on the zinc concentration in blood plasma and milk. Biol. Trace Elem. Res., 132: 112-121. https://doi.org/10.1007/s12011-0098389-7

Puchala, R., Sahlu, T. and Davis, J.J., 1999. Effects of zinc-methionine on performance of Angora goats. Small Rumin. Res., 33: 1-8. https://doi.org/10.1016/ S0921-4488(98)00194-1

Reece, W.O. and Swenson, M.J., 2008. Dukes veteriner fizyoloji. In: Kanın Bileşimi ve İşlevleri (ed. W.O. Reece). bask1, 54. Medipres, Türkiye.

Reid, R.L., Jung, G.A., Stout, W.L. and Ranney, T.S., 1987. Effect of varying zinc concentrations on quality of alfalfa for lambs. J. Anim. Sci., 64: 17351742. https://doi.org/10.2527/jas1987.6461735x

Reilly, C., 2004. Zinc. In: The nutritional trace elements. Blackwell Publishing Ltd., Oxford, UK, 
pp. 82-117.

Run, L.W., Jian, G.L., Lin, L., Li, Y.Z., Su, F.L. and Xu, G.L., 2013. Effect of zinc source on performance, zinc status, immune response, and rumen fermentation of lactating cows. Biol. Trace Elem. Res., 152: 16-24. https://doi.org/10.1007/s12011012-9585-4

Sandoval, M., Henry, P.R., Little, R.C., Cousins, R.J. and Ammerman, C.B., 1997. Estimation of the relative bioavailability of zinc from inorganic zinc sources for sheep. Anim. Feed Sci. Technol., 66: 223-235. https://doi.org/10.1016/S0377-8401(96)01103-0

Shaheen, A.A. and El-Fattah, A.A., 1995. Effect of dietary zinc on lipid peroxidation, glutathione, protein thiols levels and superoxide dismutase activity in rat tissues. Int. J. Biochem. Cell Biol., 27: 89-95. https://doi.org/10.1016/13572725(94)00053-0

Sobhanirad, S. and Naserian, A.A., 2012. Effects of high dietary zinc concentration and zinc sources on hematology and biochemistry of blood serum in Holstein dairy cows. Anim. Feed Sci. Technol., 177: 242-246. https://doi.org/10.1016/j. anifeedsci.2012.06.007

Stake, P.E., Miller, W.J., Gentry, R.P. and Neathery, M.W., 1975. Zinc metabolic adaptations in calves fed a high but nontoxic zinc level for varying time periods. J. Anım. Sci., 40: 132-137. https://doi. org/10.2527/jas $1975.401132 \mathrm{x}$
Sulu, N., Bölükbaşi, F. and Börkü, K., 1988. Merinos koyunları rumen sivisinda protozoa sayısı ve bazı protozoon tiplerinin identifikasyonu. Ankara Üniv. Vet. Fak. Derg., 35: 157-168. https://doi. org/10.1501/Vetfak_0000001125

Suttle, N.F., 2010. Mineral nutrition of livestock, $4^{\text {th }}$ ed., Chapter 16 , pp. 425-458. https://doi. org/10.1079/9781845934729.0000

Skapetas, B. and Bampidis, V., 2016. Goat production in the World: present situation and trends. Livest. Res. Rural Develop., 28: 1-9.

Ülger, H. and Coşkun, A., 2003. Çinko: Temel fonksiyonları ve metabolizması. Düzce Tip Fak. Derg., 5: 38-44.

White, C.L., Martin, G.B., Hynd, P.I. and Chapman, E., 1994. The effect of zinc deficiency on wool growth and skin and wool follicle histology of male Merino lambs. Br. J. Nutr., 71: 425-435. https://doi. org/10.1079/BJN19940149

Yuan, J.J., Xie, Y.Z., Han, C., Sun, W., Zhang, K., Zhao, J., Lu, X., Lu, J.X. and Ren, W., 2014. Determination of trace element silver in animal serum, tissues and organs by microwave digestionICP-MS. Spectrosc. Spect. Analy., 34: 2533-2537.

Zhou, X., Qu, X., Zhao, S., Wang, J., Li, S. and Zheng, N., 2017. Analysis of 22 elements in milk, feed, and water of dairy cow, goat, and buffalo from different regions of China. Biol. Trace Elem. Res., 176: 120129. https://doi.org/10.1007/s12011-016-0819-8 